Bull. Iraq nat. Hist. Mus.

(2021) 16 (4): 557-570.

https://doi.org/10.26842/binhm.7.2021.16.4.0557

\title{
MORPHOLOGY AND MOLECULAR IDENTIFICATION OF THE LARVAL STAGE OF TWO SPECIES FROM THE GENUS CHRYSOBOTHRIS ESCHSCHOLTZ, 1829 (COLEOPTERA, BUPRESTIDAE)
}

\author{
Pshtiwan A. Jalil* and Wand K. Ali** \\ *Department of Plant Protection, College of Agricultural Engineering Sciences, Salahaddin \\ University- Erbil, Iraq. \\ **Department of Biology, College of Education, Salahaddin University- Erbil, Iraq. \\ •Corresponding author's email: Pshtiwan.jalil@su.edu.krd
}

Received Date: 12 August 2021, Accepted Date: 18 Nov. 2021, Published Date: 20 December 2021

\section{ABSTRACT}

The genus of Chrysobothris Eschscholtz, 1829 is one of the most diverse and widespread genera of the family Buprestidae of some 700 described species distributed throughout the world. In Iraq, particularly in the Kurdistan region, about 4 species had been recorded so far, many of these species are sympatric, share larval host plants, and are difficult to reliably separate morphologically. The current study investigates species limits and relationships among the recognized species occurring within the Erbil Province; mitochondrial cytochrome C oxidase (COX I) molecular analysis confirmed the monophyly of two Chrysobothris species, Ch. affinis (Fabricius, 1794) and Ch. chrysostigma (Linnaeus, 1758). Implications of the resultant larval morphology and molecular techniques are discussed. Diagnostic characteristics that are depended to identifying the species within Chrysobothris in larval stage were illustrated and then compared with the molecular data.

Keywords: Buprestidae, Chrysobothris, Coleoptera, COXI, Molecular, Morphology.

\section{INTRODUCTION}

Chrysobothris Eschscholtz, 1829 is a common genus widely distributed throughout the world (MacRae and Basham, 2013). The species group within Chrysobothris in the larval stage is separated from each other by a pronotal plate, pronotal sculpture and their asperities, and the inner armament of the proventriculus (Bily, 1999). The larvae develop in the sapwood of the stems of the apricot Prunus armeniaca L., 1753, peach Prunus persica L., 1801, plum Prunus domestica L., 1753, pear Pyrus communis L., 1753 and pomegranate Punica granatum L., 1753. This genus is one of the most diverse and widespread genera of the family Buprestidae of some 700 described species distributed throughout the world (Hawkeswood, 
Morphology and molecular identification

1995; Bellamy, 2002). In Iraq, particularly in the Kurdistan Region, about 4 species had been recorded so far (Cobos, 1970; Knopf, 1971; Ali, 2007). They are Ch. affinis (Fabricius, 1794); Ch. beesoni Obenburger, 1926; Ch. beesoni kherii Cobos,1970; Ch. solieri Castelnau and Gory,1837, and Ch. parvipunctata Obenburger, 1914. But recently it has been proven that $C h$. beesoni and Ch. beesoni kherii were synonymous for Ch. parvipunctata (Löbl and Löbl, 2016, Bílý et al., 2011). Although several studies have already dealt with the adult stages of the species belonged to this genus in different areas (Holynski, 1975; Barr and Westcott, 1976; Westcott, 1983), but there was lack of comprehensive larval morphology. Accordingly, it is necessary for proper identification to provide a detailed larval description which is based not only on the optic but also on molecular technique. Furthermore, these species were found to be common and destructive pests in Kurdistan orchards. Molecular sequencing techniques provide a precise other approach to suppose evolutionary relationships among closely related species (Rubinoff et al., 2006; Hansen et al., 2015).

The main objectives of this study are to identify species levels using inferences of DNA sequences from cytochrome oxidase (COXI) and to try to determine further morphological characteristics of the larva. Eventually, differences between Ch. affinis and Ch. chrysostigma, if recognized, will not only yield information that may help in identification of larval stages, but also actually facilitate the timing and placement of insecticides to agree with activity of economically important buprestids and reduce dangerous and overpriced control measures.

\section{MATERIALS AND METHODS}

\section{Collection and identification of larval specimens}

Last instar larvae are collected from the stem of the apricot Prunus armeniaca, peach Prunus persica, plum Prunus domestica, pear Pyrus communis and pomegranate Punica granatum. The collection of the larvae has been performed in different locations of Erbil Province; the collected larvae are placed in vials containing $70 \%$ and $99 \%$ alcohol and then transferred to the laboratory for morphological and molecular study. The adult specimens have been reared from the larvae and identified with the help of the available literature (Cobos, 1986). The identification of the larval stage had been confirmed to the genus level by Dr. Mark G. Volkovitsh and Dr. Svatopluk Bílý. The morphological terminology used in the present paper follows the ones in the papers of Volkovitsh (1979), Bíý (1999) and Bíly and Volkovitsh $(2003,2005)$.

\section{Dissecting, slides preparation and imaging}

First, the larvae were dissected and boiled in $10 \% \mathrm{KOH}$ aqueous solution until the soft tissues are dissolved. After that the samples were rinsed in distilled water (Alexeev, 1960; Chamorro et al., 2012; Volkovitsh and Bílý, 2015). Second, the specimens were mounted on slides, the DPX media (a mixture of polystyrene, tricresyl phosphate and xylene) that acts as a clearing agent to decompose soft tissue was used. The dissected parts were dehydrated by rinsing in serial concentrations of alcohol $(30 \%, 50 \%, 70 \%, 90 \%$, and $100 \%)$ and then they were rinsed in xylole. Then the prepared structures were placed in DPX drops using $0.5 \mathrm{~mm}$ micro needle and covered with coverslips. The slides were placed horizontally on a hot plate at $36^{\circ} \mathrm{C}$ for $24-48$ hours until they got dried for the avoidance of bubble formation. Third, 
Jalil and Ali

images were taken by a compound microscope (Huma scope premium) with mounted LCD camera, and scaling of the displayed structures were measured by a stage micrometre.

\section{Molecular Study}

For the molecular study, we followed the procedure of Asghar et al. (2015), in which the larval specimens that had been collected and preserved in absolute ethanol and stored in refrigerator $(-20) \stackrel{\circ}{\mathrm{C}}$ until DNA extraction could be performed. A total sample size of (12) larvae were used for this experiment.

\section{DNA Extraction}

The genomic DNA of a specific tissue (i. e. thorax and abdominal segments) was extracted from a pooled sample consist of three larvae of each species. Animal and fungi DNA preparation kit (Jena Bioscience GmbH .07749 - Germany), was used.

\section{Quantification of extracted DNA}

The spectrophotometer model NanoDrop 1000 manufactured by Thermo Scientifics designed for measuring nucleic acid concentrations in sample volumes of one microliter was used. The instrument is driven by a PC, which allows $280 \mathrm{~nm}$. This ratio is used to assess the purity of DNA and RNA (Kumar et al., 2007).

\section{Agarose gel electrophoresis}

Agarose gel electrophoresis was the procedure used to separate DNA fragments based on their molecular weight and intrinsic. The technique consists of three basic steps:

1. Preparation of agarose gel.

2. Electrophoresis of DNA fragments.

3. Visualization of DNA fragments (Lee et al., 2012).

\section{Preparation to the amplification of partial Mt- COXI gene}

The PCR amplification for COXI partial gene was prepared in $25 \mu 1$ of the reaction mixture for 50 samples containing genomic DNA and 2x Taq polymerase master mix (AMPLIQON), 20 Picomol of CJ-C1-J-1718 forward primer: (5'- GGA GGA TTT GGA AAT TGA TTA GTT CC -3'), with 20 pmol of reverse primer (5'- ACT GTA AAT ATA TGA TGA GCT CA -3 '), DNase free water and template DNA by Bioresearch PTC-200 Gradient thermocycler. Temperature profile included step one is an initial denaturation at $95 \mathrm{C}^{\circ}$ for $5 \mathrm{~min}$, step two followed by 35 cycles of denaturation at $95 \mathrm{C}^{\circ}$ for 35 seconds, a primer annealing at $50 \mathrm{C}^{\circ}$ for 45 seconds, an extension at $72 \mathrm{C}^{\circ}$ for $1 \mathrm{~min}$ and final step is an extra extension at $72 \mathrm{C}^{\circ}$ for 5 min (Tabs 1, 2) (Hansen et al., 2015).

Table (1): Primer COXI used for identifying the species of the genus Chrysobothris.

\begin{tabular}{|c|c|c|c|c|c|}
\hline Primer & Direction & Target & $\operatorname{Tm} C$ & Primer sequences & Reference \\
\hline $\begin{array}{l}\text { C1-J- } \\
1718\end{array}$ & Forward & \multirow{2}{*}{$\begin{array}{l}\text { Mt- } \\
\text { COXI }\end{array}$} & \multirow{2}{*}{52} & 5'GGAGGATTTGGAAATTGATTAGTTCC3 & \multirow{2}{*}{$\begin{array}{l}\text { Hansen } \\
\text { et al. } \\
(2010)\end{array}$} \\
\hline $\begin{array}{l}\text { C1-J- } \\
1718\end{array}$ & Reverse & & & 5'ACTGTAAATATATGATGAGCTCA 3 & \\
\hline
\end{tabular}


Morphology and molecular identification

Table (2): PCR agents with their concentration and volumes.

\begin{tabular}{|c|c|c|c|}
\hline No. & PCR components & Concentration & Volume $(\mu \mathrm{l})$ \\
\hline 1 & Master Mix & $2 \mathrm{x}$ & 12.5 \\
\hline 2 & Forward Primer & $20 \mathrm{Pmol}$ & 2 \\
\hline 3 & Reverse Primer & $20 \mathrm{Pmol}$ & 2 \\
\hline 4 & DNase free Water & - & 6.5 \\
\hline 5 & Template DNA & $50 \mathrm{ng} / \mu \mathrm{l}$ & 2 \\
\hline Total & & & 25 \\
\hline
\end{tabular}

\section{DNA Sequencing}

The samples of the PCR product of the COXI mt-DNA partial gene had been sequenced by ABI Prism Terminator Sequencing Kit (Applied Biosystem) at the Immuno gene Center, Physician's Street in Erbil. Chromatograms of primers gene were edited and also checked using Finch TV and chromas program software. Some of the products were prepared and sent to the Republic of Korea (South), and sequenced by the molecular and genetic company; Macro Gene Company.

\section{RESULTS}

Chrysobothris affinis (Fabricius, 1794)

Larval morphology

Body shape and length: Larval body (Pls. $1 \mathrm{a}, \mathrm{b}$ ) relatively large, long and slender, and belongs to the usual Buprestoid larval type (morpho-ecological group 2) (Volkovitsh, 1979). Length of mature larva $25-27 \mathrm{~mm}$; prothorax strongly enlarged, its width 5.5-6 mm.

Head: Conical-shaped, nearly rounded anterior margin. Epistome (Pl. 1 c), heavily sclerotized, and about five times as wide as long; anterior margin slightly emarginated between globular condyles, posterior margin bisinus; lateroposterior corners sharp, epistomal sensilla centrally located, and each group of epistomal sensilla, consisting of long trichosensilla and one basiconic sensillum. Antennae ( $\mathrm{Pl} .1 \mathrm{~d}$ ), basal antennomere nearly round, campaniform sensillum located on dorsal side; apical crown of microspinulae weakly developed with sparse and short microspinulae. Apical antennomere shorter and smaller, two times as wide as long; apical crown of microspinulae with sparse and short microspinulae; apical trichosensilla long and sharp; apical cavity shallow, and provided with sharp sensory appendage, two palmate and one tiny basiconic sensillum that very close bases.

Mandibles (Pl. 1 e): Triangular, dark brown; strongly sclerotized, posterior part have two very small pores and short, thick seta. Apical part with three sharp teeth; cutting edge with two obtuse denticles. Ante-clypeus and labrum (Pl. 1 f), membranous, smooth, and about thrice as wide as long. Labrum trapezoid, longer than wide, anterior margin noticeably rounded and covered by a narrow field of microsetae; palatine sclerite well developed, lateral branches carried long trichosensilla; medial branches with a pair of long apical trichosensilla that prolonged to anterior margin, two campaniform sensilla located between lateral and medial branches. Labio-maxillary complex, prementum, expanded and detached with basal sclerite of 
cardo. Labium (Pl. $1 \mathrm{~g}$ ), bottle-shaped; anterior margin widely rounded, corner sclerite of prementum well sclerotized and carried long sharp seta, with five campaniform sensilla; medial part with two zones of dense microspinulae. Maxillae (Pl. $1 \mathrm{~h}$ ), cardo slightly rounded and glabrous; stipes bowed inward with densely microspinulae. Basal palpomere of maxillary palpus, sub-cylindrical, wider than long; anterior margin with few short microspinulae and long lateral seta. Apical palpomere, conical, with acutely curved sensillum, and one campaniform sensillum; upper part provided with five tiny sensory cones. Mala, thick and slightly cylindrical; well sclerotized, with six external long sensilla, and one campaniform sensillum.

Thorax, prothorax wide and flattened, pronotal plate well- developed, and sculptured with dark, dense, asperities and sparse micro teeth (Pl. 1 i); prosternal plate with same features but differ from by narrowing of border and forming concavity. Pronotal groove (Pl. $1 \mathrm{j}$ ) inverted letter V; prosternal groove, straight and narrow, not extended to the outer border (Pl. $1 \mathrm{k}$ ); mesothorax, transverse and four times as wide as long with medial narrowing; metathorax, transverse and slightly narrower and longer than mesothorax.

Spiracles: Mesothoracic spiracles (Pl. $1 \mathrm{~L}$ ), reniform, and about 3.5 times as wide as long with dense trabeculae. Abdominal spiracles (Pl. $1 \mathrm{~m}$ ) smaller and spherical shaped with widely reniform.

Proventriculus: Inner armaments of proventriculus developed as a single long protrusion with long and sharp spines (Pl. $1 \mathrm{n})$.

Abdomen (Pl. 1 a): Relatively long and extremely flattened, first abdominal segment nearly ovoid without lateral folds; segments 2-8 slightly equal in width and length, dorsolateral folds well developed; anal segment sub conical with vertical anal rim; outer surface of the body, covered with dense, short microspinulae and long setae (Pl. 1 o). 
Morphology and molecular identification

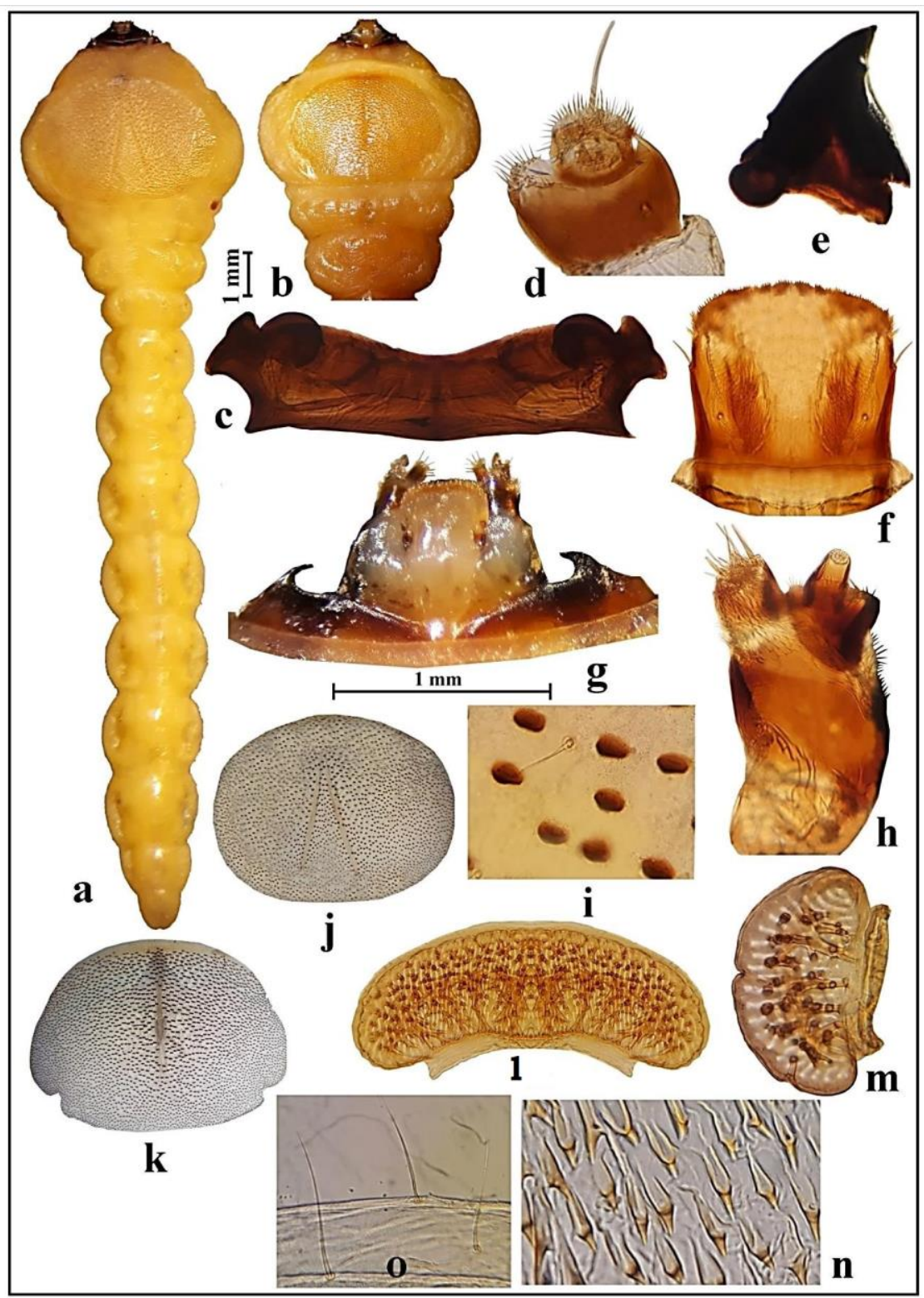

Plate (1): Habits and morphological characteristics of the larva of Ch. affinis; (a) Dorsal view of larval body, (b) Ventral view of thorax, (c) Epistome, (d) Antenna, (e) Mandible, (f) Labrum, (g) Labiomaxillary complex, (h) Maxilla, (i) Pronotal asperities, (j) Pronotal plate with groove, (k) Prosternal plate with groove, (l) Mesothoracic spiracle, (m) abdominal spiracle, (n) Inner armament of proventriculus, (o) Body surface. 
Chrysobothris chrysostigma (Linnaeus, 1758)

Larval morphology

Body length and shape (Pls. 2 a, b) larva, relatively large, and flattened with pale yellow color; pronotal, and prosternal plate well developed, with nearly circular border; length of mature larva about 25-28 mm; width of prothorax about 5-5.5 mm.

Head: Flattened prominent, expanded at base; surface provided with short and dense microspinulae. Epistome (Pl. 2 c), transversely elongated, strongly sclerotized. 4.5 times as wide as long; anterior margin darkened and deeply incurved between semi-rounded condyles, posterior margin slightly bisinus with sharp posteriolateral corners, epistomal sensilla near with each other, and each group with two rather short trichosensilla and one basiconic sensillum. Antennae (Pl. 2 d), basal antennomere transversely, sub-cylindrical, and nearly 1.2 times as long as wide, with campaniform sensillum on the dorsal side; slightly narrowed, basally. Apical antennomere short and wide and about thrice as wide as long, the apical crown of microspinulae well developed, with long and dense microspinulae; apical trichosensilla curved long; apical cavity shallow, well developed and provided with short, sharp sensory appendage, two palmate sensilla, and one tiny basiconic sensillum. Mandibles (Pl. 2 e), triangle-shaped, strongly sclerotized, and expanded basally; apical teeth with three sharp teeth; hind seta short and thick. Ante-clypeus and labrum (Pl. 2 f), membranous, smooth, and about thrice as wide as long. Labrum, trapezoid, longer than wide; anterior margin slightly arched toward mouth cavity, and covered by dense and short microsetae; anterolateral corners round with one long seta and one campaniform sensillum; anterolateral lobes weakly developed; lateral branches strongly developed with long, thick tricosensilla, medial branches with long, sharp apical seta, in which nearly prolonged to anterior microspinuled area. Labio-maxillary complex (Pl. 2 g), prementum, transverse, anterior margin with medial depressing. Labium oblique; anterior margin widely rounded, corner sclerite, tubular, well developed, with long sharp seta and five campaniform sensilla; medial part with two microspinulae zones. Maxillae (Pl. 2 h), cardo round, with few short setae. Stipes strongly sclerotized, anterior margin of stipes with a bundle of long setae, and prolonged to near bases of maxillary palpus. Basal palpomere of maxillary palpus, barrel-shaped, longer than wide, with medial campaniform sensillum; anterior margin with dense and short microspinulae; apical palpomere, cylindrical; two times as long as wide, with four tiny sensory cones. Mala, sub-conical shaped, well sclerotized, longer than wide, with six long and thick tricosensilla, and fine dens microsetae.

Thorax (Pls. 2 a, b): Prothorax ovoid bordered, and well expanded, both pronotal and prosternal plates well-developed and covered by dense, dark brown and, dash shaped asperities with micro sculpture, (Pl. 2 i); pronotal groove inverted "V" letter, and branches connected in apical part, and remarkably diverged posteriorly ( $\mathrm{Pl} .2 \mathrm{j}$ ), prosternal groove straight with tightly tapering ends (Pl. 2 k). Mesothorax, ring-shaped; short, and four times as wide as long; metathorax, slightly transverse, about thrice as wide as long with slightly medial depressions, and basal narrowing; leg rudiments absent.

Spiracles: Mesothoracic spiracles (Pl. 2 1) reniform, three times as wide as long, and arcuated medially; with dense, vertical trabeculae. Abdominal spiracles (Pl. 2 m), slightly spherical 
with fewer branches of trabeculae and expanded peretreme. Proventriculus (Pl. 2 n), inner armament of frontal and basal part provided with long and dense microspines; medial part with irregular sculptures in which developed as micro tubercles and carried 2-4 short and sharp micro spines.

Abdomen (Pl. 2 a): Large, and relatively long flattened, first abdominal segment nearly ovoid and distinctly narrower than metathorax and second abdominal segment; segments 2 - 8 slightly wider than long; dorsolateral folds well developed; last segment triangular, and opened with vertical anal rim; whitish dense and short microspinulae covered the whole abdominal surface with presence sparse singular, long bristles (Pl. 2 o). 
Jalil and Ali

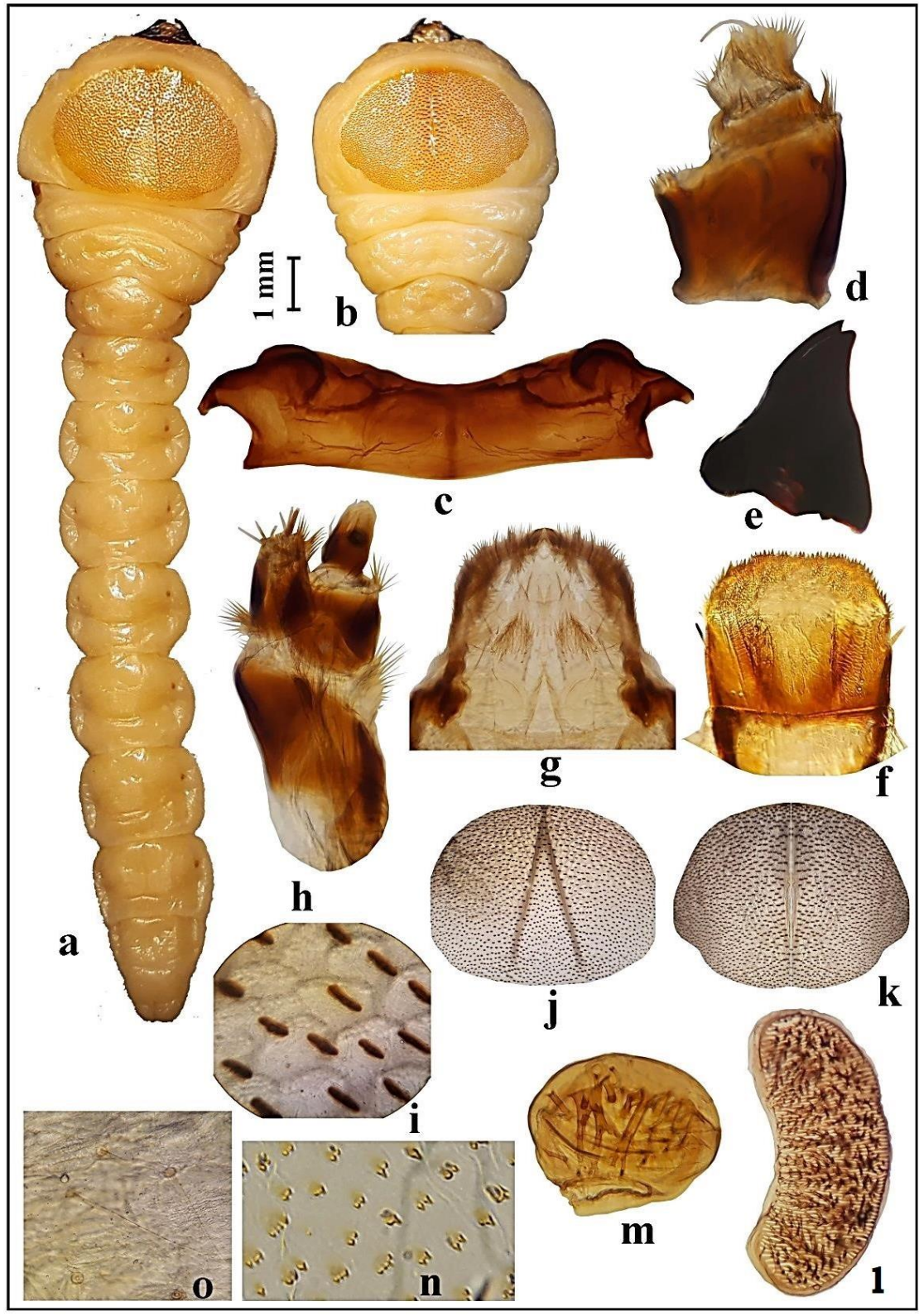

Plate (2): Habits and morphological characteristics of the larva of Ch. Chrysostigma; (a) Dorsal view of larval body, (b) Ventral view of thorax, (c) Epistome, (d) Antenna, (e) Mandible, (f) Labrum, (g) Labium, (h) Maxilla, (i) Pronotal asperities, (j) Pronotal plate with groove, (k) Prosternal plate with groove, (l) Mesothoracic spiracle, (m) abdominal spiracle, (n) Inner armament of proventriculus, (o) Body surface. 
Morphology and molecular identification

\section{Molecular study}

Genomic DNA for the two specimens belonging to the genus Chrysobothris includes $C h$. affinis (Fabricius, 1794) and Ch. chrysostigma were isolated. The purity was also found acceptable ranging between (1.7-1.8) determined by spectrophotometer ratio $\mathrm{A}_{260} / \mathrm{A}_{280}$. The molecular weight of the genomic DNA samples was estimated using $1 \%$ agarose gel electrophoresis containing $\lambda$ DNA samples as control and it was found to be the range $50 \mathrm{~kb}$ (Pl. 3). The lanes from 1-2b represent the two species respectively; lane $M$ represents unrestricted $\lambda$ DNA as a standard molecular weight marker $\sim 50 \mathrm{~kb}$. Partial of the COXI gene segments for all the collected specimens was amplified by a universal primer (Wild and Maddison, 2008). The molecular size of DNA amplicons was estimated using $1.5 \%$ agarose gel electrophoresis. By using this primer, one single and strong intense band of amplified product of the mt-DNA gene had been produced across the studied species, with molecular weight approximately $650 \mathrm{bp}$, and clearly could be noted as shown in ( $\mathrm{Pl} .3)$.

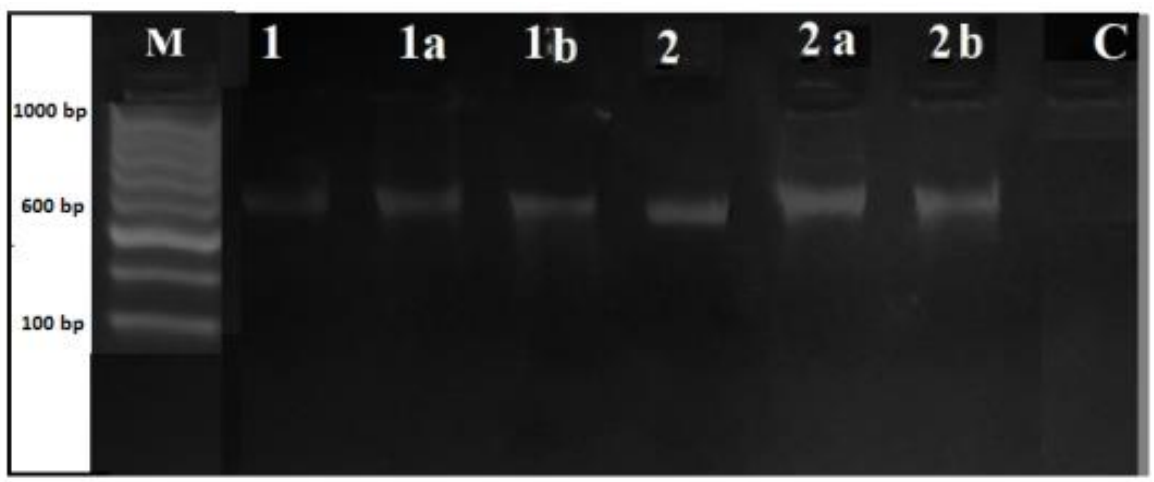

Plate (3): Amplification results obtained by using universal primer complementary to regions encoding $\mathrm{mt}$ COXI gene. Electrophoresis was performed on $(1.5 \%)$ agarose gel for min. Lane 1 indicates DNA molecular weight $100 \mathrm{bp}$ size ladder The lanes from $1-2 b$ represent the studied species.

\section{Sequence Alignment}

The gene sequences were applied to basic local alignment search tool (BLAST) to blast the sequences and alignment which is available at the national center for biotechnology information (NCBI) website to comparing and alignment query sequence with other biological sequences to find out the similarity with the matched species (Ellis et al., 2009).

\section{DISCUSSION}

Being compatible with the characteristics used in the keys of the Buprestidae larvae published by Cobos (1986) and Bilý (1999), several morphological characters were selected to describe and identify the larvae of Chrysobothris species. This study is based on more morphological details of the larval stage of Ch. affinis and Ch. chrysostigma which contribute significantly to the accuracy of larval description and identification. Molecular study has rarely used for the confirmation of the identification of buprestid larvae. Earlier studies indicate that the molecular technique is reliable and important for the verification of 
Jalil and Ali

morphological description of larval stage and its correct differentiation from the other species of the same genus (Hansen et al., 2015). Usually, the immature stages of the insect species are very difficult to distinguish and correctly identify based on external characters. The results of our study provide additional characteristics to the morphology and diagnosis of two different species in the larval stage. We recommend, however, caution that absent the presence of more informative nuclear sequence data, discrimination of these species group members using the repertoire of anatomical structures in current use is insufficient to reliably place specimens into taxonomically defined entities. We suggest that future molecular investigations of species limitations of Chrysobothris group members should implement a population genetics approach using several speedily evolving nuclear genes, which would be most definitely acquired successive to a NextGen sequencing campaign.

\section{CONCLUSIONS}

In this study the larval stage of two different species of the genus Chrysobothris were described and illustrated morphologically. The larval specimens were collected in Erbil Province in the Iraqi Kurdistan Region. Two complementary methods of identification (morphological description and molecular technique) were utilized for analyzing the species identification in larval stage and recognizing as two dangerous horticultural pests in the future Two species Ch. affinis and Ch. chrysostigma have been recorded for the first time in GeneBank with their accession numbers (MN066129 and MN066128) respectively that confirmed the identification of these species precisely.

\section{ACKNOWLEDGEMENT}

We would like to express our deepest gratitude to Dr. Mark G.Volkovitsh (St. Petersburg, Russia), and Dr. Svatopluk Bílý (Prague, Czech Republic), for their assistance in the identification of the larval and adult specimens. We would like also to thank all our colleagues in Plant Protection Department, College of Agricultural Engineering Sciences, Salahaddin University - Erbil, Kurdistan region, Iraq for their cooperation of this work.

\section{CONFLICT OF INTEREST STATMENT}

The authors have no conflicts of interest to declare.

\section{LITERATURE CITED}

Alexeev, A. 1960. On the morphology and systematics of larvae of some species of the genus Agrilus Curt. in the European part of the USSR (Coleoptera, Buprestidae). Zoologicheskii Zhurnal, 39:1497-1510.

Ali, W. K. 2007. Taxonomic study of the flat headed steam borers of Buprestidae (Coleoptera) in Iraqi Kurdistan. Ph. D. dissertation, in Zoology department of Biology, College of Science, Baghdad University, 205 pp.

Asghar, U., Malik, M. F., Anwar, F., Javed, A. and Raza, A. 2015. DNA extraction from insects by using different techniques: a review. Advances in Entomology, 3(4): 132 138. 
Morphology and molecular identification

Barr, W. F. and Westcott, R. L. 1976. Taxonomic, biological and distributional notes of North American Chrysobothris, with the description of a new species from California (Coleoptera: Buprestidae). The Pan-Pacific Entomologist, 52(2): 138-152.

Bellamy, C.L. 2002. Nomenclatural and taxonomic changes, new distribution and biological records for jewel beetles (Coleoptera: Buprestidae). Insecta Mundi, 16 (1-3): 57- 63.

Bilý, S. 1999. Larvae of buprestid beetles (Coleoptera: Buprestidae) of Central Europe. Acta Entomologica Musei Nationalis Pragae, Supplementum 9: 1-45.

Bílý, S. and Volkovitsh, M. G. 2003. Larvae of Australian Buprestidae (Coleoptera). Part 1. Genera Austrophorella and Pseudotaenia. Acta Societatis Zoologicae Bohemicae, 67: 99-114.

Bily, S. and Volkovitsh, M. G. 2005 Larvae of Australian Buprestidae (Coleoptera) Part 3. Genera Maoraxia and Anthaxoschema with a review of larval characters of known anthaxiine taxa. Folia Heyrovskyana, 13:29-48.

Bílý, S., Kubáň, V., Volkovitsh, M. G. and Kalashian, M. Yu. 2011. Order Coleoptera, Family Buprestidae. Arthropod Fauna of the UAE, 4: 168-223.

Chamorro, M. L., Volkovitsh, M. G., Poland, T. M., Haak, R. A. and Lingafelter, S. W. 2012. Preimaginal stages of the emerald ash borer, Agrilus planipennis Fairmaire (Coleoptera: Buprestidae): An invasive pest on ash trees (Fraxinus). PLoS One, 7:1-12.

Cobos, A. 1986. Fauna iberica de coleopteros Buprestidae. Imp Aguirre, Madrid, 364 pp.

Cobos, A. 1970. Estudio sobre un nuevo Chrysobothris del Iraq, de interes agricola. Archivos de Instituto de Aclimatación, 15:189-196.

Ellis, J., Blackshaw, R., Parker, W., Hicks, H. and Knight, M. 2009. Genetic identification of morphologically cryptic agricultural pests. Agricultural and Forest Entomology, 11: 115-121.

Hansen, J. A. 2010. Identification and phylogenetic characterization of select species of Buprestidae (Coleopteran) and Sesiidae (Lepidoptera) wood boring insect families occurring across the Southeastern United States. Ph.D. dissertation, University of Tennessee, $220 \mathrm{pp}$.

Hansen, J. A., Moulton, J. K., Klingeman, W. E., Oliver, J. B., Windham, M. T., Trigiano, R. N. and Reding, M. E. 2015. Molecular systematics of the Chrysobothris femorata species group (Coleoptera: Buprestidae). Annals of the Entomological Society of America, 108: 950 - 963. 
Jalil and Ali

Hawkeswood, T. J. 1995. A new species of the genus Chrysobothris Eschscholtz, (Coleoptera: Buprestidae) from Australis. Giornale Italiano di Entomologia, 7: 345-349.

Holyński, R. B. 1975. A new European species of the genus Chrysobothris Esch. (Coleoptera, Buprestidae). Polskie Pismo Entomologiczne, 45:357-363.

Knopf, H. E. 1971. Contributions to the knowledge of the insect fauna of trees in Iraq. Part I. Coleoptera. Zeitschrift für Angewandte Entomologie, 69: 82 - 87.

Kumar, N. P., Rajavel, A. R., Natarajan, R. and Jambulingam, P. 2007. DNA barcodes can distinguish species of Indian mosquitoes (Diptera: Culicidae). Journal of Medical Entomology, 44 (1): 1 - 7.

Lee, P. Y., Costumbrado, J., Hsu, C.Y. and Kim, Y. H. 2012. Agarose gel electrophoresis for the separation of DNA fragments. Journal of Visualized Experiments, 62: 3923.

Löbl, I. and Löbl, D. (eds.). 2016. Catalogue of Palaearctic Coleoptera. Scarabaeoidea, Scirtoidea, Dascilloidea, Buprestoidea and Byrrhoidea, Vol. 3. Revised and Updated Edition. Brill, Leiden-Boston, 983 pp.

MacRae, T. C. and Basham, J. P. 2013. Distributional, biological and nomenclatural notes on Buprestidae (Coleoptera) occurring in the U.S.A. and Canada. The Pan Pacific Entomologist, 89 (3): 125-142.

Rubinoff, D., Cameron, S. and Kipling, W. 2006. A genomic perspective on the shortcomings of mitochondrial DNA for barcoding and DNA taxonomy. Journal of Heredity, 97: 581-594.

Volkovitsh, M. G. 1979. K morfologii lichinok zlatok roda Acmaeoderella Cobos (Coleoptera, Buprestidae). [On the larval morphology of buprestid beetles of the genus Acmaeoderella Cobos (Coleoptera, Buprestidae)]. Trudy Zoologitscheskogo Instituta Akademii Nauk SSSR, 83: 21-38. (In Russian).

Volkovitsh M. G. and Bílý, S. 2015. Larvae of Australian Buprestidae (Coleoptera). Part 5. Genera Astraeus and Xyroscelis, with notes on larval characters of Australian polycestine taxa. Acta Entomologica Musei Nationalis Pragae, 55: 173-202.

Westcott, R. L. 1983. Revision of the aerea group of Chrysobothris (Coleoptera: Buprestidae). Systematic Entomology, 8:339-359.

Wild, A. L. and Maddison, D. R. 2008. Evaluating nuclear protein-coding genes for phylogenetic utility in beetles. Molecular Phylogenetics and Evolution, 48: 877- 891. 
Bull. Iraq nat. Hist. Mus.

(2021) 16 (4): 557-570

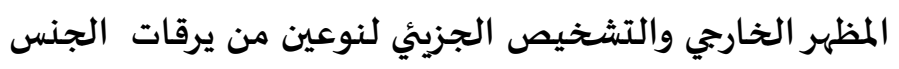

Chrysobothris Eschscholtz, 1829

\section{(Coleoptera, Buprestidae)}

بشتيوان عبدالله جليل* و وند خالص علي **

* قسم وقاية النبات، كلية علوم الهندسة الزراعية، جامعة صلاح الدين،أربيل، العراق. ** قسم علوم الحياة، كلية التربية، جامعة صلاح الدين،أربيل، العراق.

تأريخ الاستلام: 2021/08/12، تأريخ القبول: 2021/11/18، تأريخ النشر: 2021/12/20

\section{الخلاصة}

الجنس Chrysobothris Eschscholtz, 1829 هو احدى أكثر الأجناس تنوعًا وانتشارًا

في عائلة Buprestidae حيث سجل لها حوالي 700 أنواع موصوف منتشرة في جميع أنحاء العالم. اما في العراق، سجل 4 أنواع ضمن إقليم كردستان؛ وهذه الأنواع مستوطنة وعوائلها النباتية مشتركة ويصعب تميزهم مظهريًا على نحو موثوق.

بحثت الدراسة الحالية عن مدى الأنواع وكذلك العلاقات بين الأنواع الاخرى

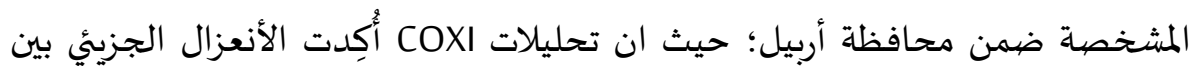
نوعين من جنس Chrysobothris و هما كل من: Ch. affinis (Fabricius, 1794)

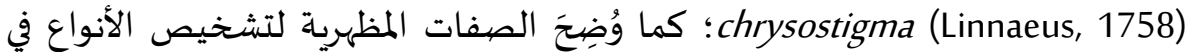
الطور اليرقي الاخيروتم مقارنتها مع البيانات الجزيئية. 